
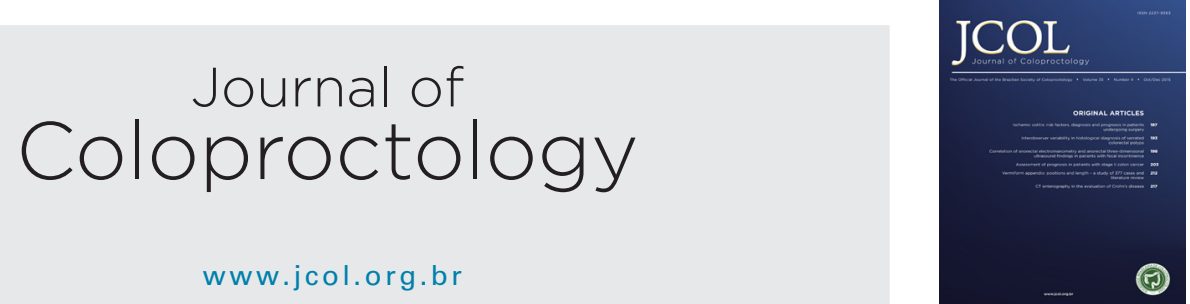

Technical Note

\title{
Local irrigation with silver nitrate, a non-surgical approach for persistent anal fistula
}

\section{Carlos Placer-Galán, Ignacio Aguirre-Allende*, José María Enriquez-Navascués}

Hospital Universitario Donostia, Department of Surgery, Colorectal Unit, San Sebastián, Spain

\section{A R T I C L E I N F O}

\section{Article history:}

Received 14 May 2018

Accepted 3 October 2018

Available online 2 November 2018

Keywords:

Persistent anal fistula

Silver nitrate

Non-surgical

Complications

\begin{abstract}
A B S T R A C T
Purpose: Treatment of persistent anal fistula implies a major challenge for surgeons, with risk of additional recurrence and potential continence impairment. We present a nonsurgical treatment based on irrigation with silver nitrate $1 \%$ solution.

Methods: This is a prospective study including patients with persistent anal fistula after surgery, who were treated with silver nitrate 1\% solution irrigation from May 2015 to March 2017. Patients with evidence of abscess, presence of $>1$ external opening and those with bowel inflammatory disease were excluded. $3-5$ cc of silver nitrate $1 \%$ solution were instilled through a catheter. The procedure was repeated on a weekly basis, conducting a maximum of 7 sessions per patient.

Results: 18 patients (13 male, 72.2\%) with a median age of 48 years old (IQR 41-55) were treated using silver nitrate $1 \%$ solution. A median of 5 sessions per patient was performed (IQR 3-6). The median follow-up period was 18 months (IQR 9-25). After the described period 8 patients' (44.4\%) presented complete resolution of the fistula, 2 patients' $(11.2 \%)$ were classified as partial healing and in 8 patients' (44.4\%) the treatment was considered to fail. 6 patients' experienced self-limited pain during instillation, with persistence up to $24 \mathrm{~h}$ in 2 of them.

Conclusions: Treatment with silver nitrate $1 \%$ solution is a minimally invasive procedure, with a favourable safety profile, that can be performed in an outpatients' basis achieving a complete healing rate of $44.4 \%$. Therefore, this method should be considered for the treatment of recurrent or persistent anal fistula.

(c) 2018 Sociedade Brasileira de Coloproctologia. Published by Elsevier Editora Ltda. This is an open access article under the CC BY-NC-ND license (http://creativecommons.org/ licenses/by-nc-nd/4.0/).
\end{abstract}

\footnotetext{
* Corresponding author.

E-mail: ignacioaguirreallende@gmail.com (I. Aguirre-Allende).

https://doi.org/10.1016/j.jcol.2018.10.004

2237-9363/@ 2018 Sociedade Brasileira de Coloproctologia. Published by Elsevier Editora Ltda. This is an open access article under the CC BY-NC-ND license (http://creativecommons.org/licenses/by-nc-nd/4.0/).
} 


\title{
Irrigação local com nitrato de prata, uma abordagem não cirúrgica para fístula anal persistente
}

\author{
R E S U M O
}

Palauras-chave:

Fístula anal persistente

Nitrato de prata

Não cirúrgico

Complicações
Objetivo: O tratamento da fístula anal persistente é um grande desafio para os cirurgiões, com risco de recorrência adicional e potencial comprometimento da continência. Os autores apresentam um tratamento não cirúrgico baseado na irrigação com solução de nitrato de prata a $1 \%$.

Métodos: Este foi um estudo prospectivo incluindo pacientes com fístula anal persistente após a cirurgia que foram tratados com irrigação com solução de nitrato de prata a 1\% entre maio de 2015 e março de 2017. Pacientes com evidência de abscesso, presença de mais de uma abertura externa e aqueles com doença inflamatória intestinal foram excluídos. Usando um cateter, instilou-se 3 a 5 cc. de solução de nitrato de prata a 1\%. O procedimento foi repetido semanalmente, em um máximo de sete sessões por paciente.

Resultados: Um total de 18 pacientes (13 homens, 72,2\%) com idade mediana de 48 anos (IQR 41-55) foram tratados com solução de nitrato de prata a $1 \%$. Uma mediana de cinco sessões por paciente foi realizada (IQR 3-6). A mediana do período de acompanhamento foi de 18 meses (IQR 9-25). Após o período descrito, oito pacientes $(44,4 \%)$ apresentaram resolução completa da fístula, dois pacientes $(11,2 \%)$ foram classificados como cicatrização parcial e em oito pacientes $(44,4 \%)$ o tratamento falhou. Seis pacientes apresentaram dor autolimitada durante a instilação, que persistiu por até 24 horas em dois deles.

Conclusões: O tratamento com solução de nitrato de prata a $1 \%$ é um procedimento minimamente invasivo, com perfil de segurança favorável, que pode ser realizado em regime ambulatorial, atingindo taxa de cura completa de $44,4 \%$. Portanto, este método deve ser considerado para o tratamento da fístula anal recorrente ou persistente.

(C) 2018 Sociedade Brasileira de Coloproctologia. Publicado por Elsevier Editora Ltda. Este é um artigo Open Access sob uma licença CC BY-NC-ND (http://creativecommons.org/ licenses/by-nc-nd/4.0/).

\section{Introduction}

Approximately one third of the patients with complex anal fistula, defined as those not eligible for simple fistulotomy, recur after surgical treatment independently of the performed technique. Therefore, there is no gold-standard surgical procedure for the complex anal fistula. Although fistulotomy has proven to succeed in approximately $80 \%-95 \%$ of the patients, this is mostly for low anal fistula cases. Treatment of recurrent anal fistula after surgery represents a major challenge for the surgeon, having to deal with the risk of additional recurrence and potential continence impairment. ${ }^{1}$

In 2014 Attaallah et al. first reported encouraging results supporting conservative treatment of anal fistula using a silver nitrate (SN) $1 \%$ solution, with a complete resolution rate up to $52 \% .^{2} \mathrm{SN}$ is known to have an antiseptic action and the capacity to produce a chemical burn destroying the surrounding granulation tissue ${ }^{3}$ favouring cicatrization.

The aim of this brief communication is to report our perspective in the conservative treatment of recurrent anal fistula using irrigation of SN solution.

\section{Methods}

This is a prospective single arm study including patients with persistent anal fistula after surgery, who were treated with
SN 1\% solution irrigation. The study was performed from May 2015 until March 2017. This study received the approval of the Bioethical and Clinical Research committee of the hospital.

\section{SN solution irrigation technique}

A complete physical examination, anoscopy and additional imaging tests, such as endoanal ultrasonography (edoanal-US) and/or MRI, were performed to establish diagnosis. Patients with evidence of associated abscess or cavity, presence of $>1$ external opening or bowel inflammatory disease were excluded. The presence of seton was not considered an absolute contraindication. It was removed 8 weeks after its placement, prior to the commence of the treatment with SN $1 \%$ solution. The procedure was conducted in the outpatients' clinic with no need of any previous local or intestinal preparation. Prophylactic antibiotic therapy was not administered during or after the treatment session. Patients who underwent for the treatment were positioned in left-lateral position. After complete physical examination, digital rectal examination and anoscopy; an 18 Gauge (18G) catheter was placed in the external opening of the fistula (Fig. 1). Subsequently, a $3-5$ cc of SN 1\% solution were irrigated trough the catheter in the depth of the fistula. It is necessary to evince the flow of SN $1 \%$ solution trough the internal opening of the fistula. Patients with LIFT surgery were the exception, due to the absence of an internal opening. In cases of long fistula tracts, the internal opening was sealed performing a digital rectal examination, 


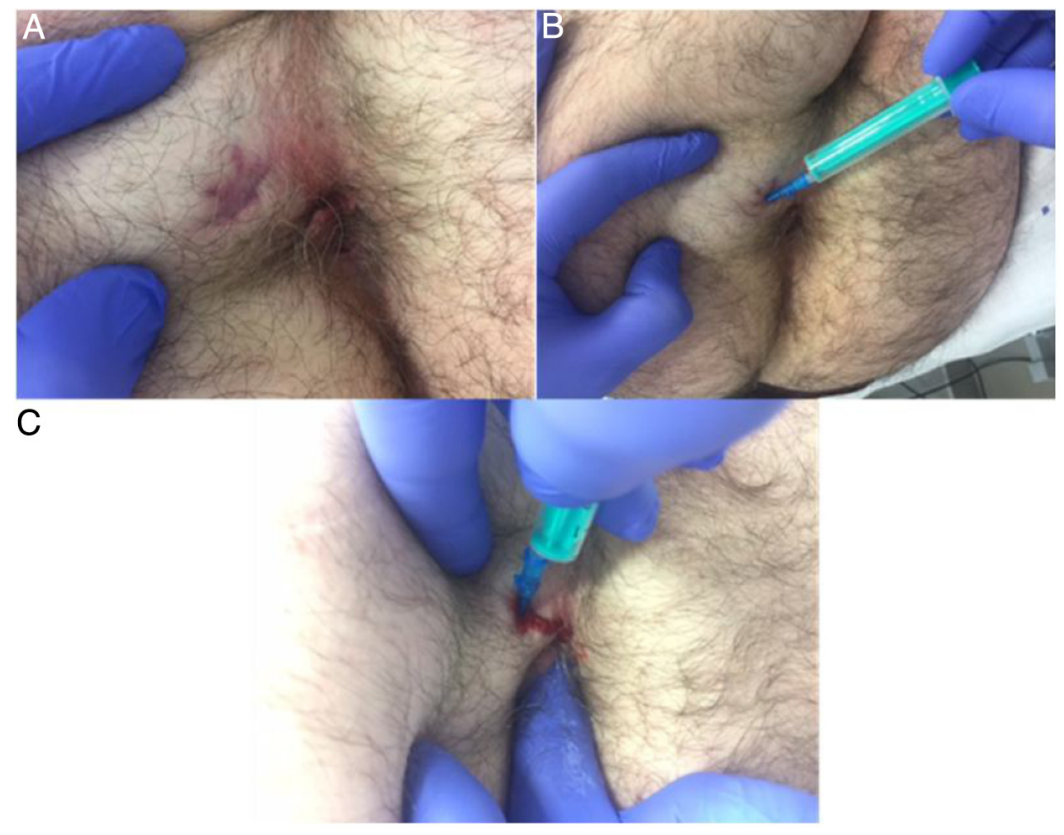

Fig. 1 - Procedure technique, external approach. Patient with an anterior transsphincteric anal fistula, lithotomy position. (A) External opening of the anal fistula. (B) Abbocath $18 \mathrm{G}$ catheter positioned through the external opening of the fistula. (C) The abbocath catheter is positioned through the external opening in the fistula tract, while the internal opening was sealed performing a digital rectal examination, increasing the filling pressure.

increasing the filling pressure. The excess SN 1\% solution was not removed from the anal canal. In the first cases of our series, the treatment was performed under anoscopy control in order to assess the effects of the irrigation on the anal mucosa. This treatment methodology was repeated on a weekly basis, conducting a maximum of 7 treatment sessions per patient.

\section{Follow-up}

Complete resolution was defined as the absence of clinical manifestations and evidence for complete epithelization of the external opening. Partial healing was considered when the external opening persisted despite partial epithelization signs, in the absence of clinical symptomatology and/or suppuration. Treatment failure was considered when the fistula and its external opening persisted, together with clinical evidence of suppuration of any characteristics. Follow up controls were performed 1 month, 3 months and 1 year after termination of the treatment. Data regarding adverse effects during treatment and follow up period were collected.

\section{Statistical analysis}

Continuous data are expressed as medians (with IQR) and compared using. Categorical data were expressed as frequencies and percentages. Data were analyzed using SPSS (version 21. for Windows; SPSS Inc., Chicago, IL, USA).

\section{Results}

A total of 18 patients (13 male; $72.2 \%$ ) were included, with a median age of 48 years old (IQR 41-55). Previous surgeries were:
6 endorectal advancement flaps, 6 fistulotomies, 4 Ligations of Intersphincteric Fistula Tract (LIFT) and 2 fistulotomies plus sphincteroplasties. 16 patients presented a transsphincteric fistula; and additionally, 2 cases of residual track in absence of endoanal communication after LIFT surgery were included. Fig. 1 summarizes the patient population evaluated in the time period and finally selected study population (Fig. 1). A median of 5 sessions per patient was performed (IQR 3-6). The median follow-up period was 18 months (IQR 9-25). After the described follow-up period 8 patients (44.4\%) presented complete resolution of the fistula, 2 patients $(11.2 \%)$ were classified as partial healing and in 8 patients (44.4\%) the treatment was considered to fail. Among patients presenting complete resolution of the fistula external opening closure varied from 2 to 4 weeks.

Procedure success rates were similar by age, sex and/or tobacco consumption. However, Body Mass Index (BMI) was higher among patients with treatment failure criteria. In terms of adverse effects, 6 patients experienced self-limited pain during instillation of SN $1 \%$ solution; with persistence up to $24 \mathrm{~h}$ in 2 of them. There were no major complications related with the SN solution irrigation, including proctitis; and none of the patients reported faecal incontinence during follow up period. 6 patients with persistent anal fistula underwent surgery after the described procedure, with no complications or major surgical difficulties attributable to local chemical treatment.

\section{Discussion}

In presence of a recurrent or persistent complex anal fistula, local conservative treatment with SN 1\% solution instillation is an alternative that should be considered. The ideal patient 


\begin{tabular}{|c|c|c|c|c|c|}
\hline Study & Solution & $\begin{array}{l}\text { Patients (pri- } \\
\text { mary/recurrent) }\end{array}$ & No. sessions & Follow-up (months) & $\begin{array}{l}\text { Healing } \\
(\%)\end{array}$ \\
\hline Tomasello et al. $(2012)^{3}$ & Argentum-quarz & $3 / 0$ & 16 & 4 & $2(66.6)$ \\
\hline Utsunomiya et al. (2014) $)^{7}$ & Liquid SN $30 \%$ & $113 / 0^{a}$ & $1-3$ & $?$ & $82(73)$ \\
\hline Attaallah et al. $(2015)^{2}$ & Liquid SN 1\% & $56 / 4$ & $1-10$ & 10 & $29(52)$ \\
\hline Doll et al. $(2015)^{4}$ & Liquid SN 5\% & $15 / 0$ & $?$ & & $4(27)$ \\
\hline Attaallah et al. $(2015)^{5}$ & Liquid SN 1\% & $186 / ?$ & $?$ & 16 & $115(62)$ \\
\hline Placer et al. & Liquid SN 1\% & $0 / 18$ & $2-7$ & 18 & $8(44)$ \\
\hline
\end{tabular}

that would benefit from SN 1\% solution local treatment is that patient with absence of intermediate abscess and/or cavity, with a persistent anal fistula after surgery; that potentially would require additional complex surgeries. We report a complete healing rate up to $44 \%$ with no major complications. Furthermore, in our experience, local instillation with SN did not have significant impact on additional surgeries outcomes.

Silver salt, and its' active biological ion $\left(\mathrm{Ag}^{+}\right)$, had been described to act in two phases. An early phase, also known as "fast effects phase", caused by denaturing effect of silver ion $\left(\mathrm{Ag}^{+}\right)$upon cell proteins; and a second and late phase. This late phase is also described as the "sustained effects phase" in which silver proteinate experiences a progressive ionization, causing a slow but long-acting effect. It also known that $\mathrm{SN}$ has an antiseptic effect, ${ }^{3}$ which is based on the protein denaturalization of the bacterial cell wall and membrane. Antimicrobial properties of silver are dependent upon release of biologically active silver ion $\left(\mathrm{Ag}^{+}\right)$from $\mathrm{SN}$. The instillation of a SN solution allows to reach all the tracts and therefore maximizing its' effects.

Several case series have been published evaluating SN solution irrigation treatment; these studies are summarized in Table 1 (Table 1). Attaallah et al. reported a 52\% (29-56 cases) rate of complete clinical response for non-recurrent fistula and a 50\% (4-8 cases) rate for patients with recurrent fistula, with a follow up period of 10 months. ${ }^{2}$ These results are similar to the data we present in our case series. However, we must point out that our treatment procedure differs from that performed by Attaallah et al.; since we performed the treatment sessions on weekly basis. All this data has been questioned in a small case series of 15 patients, with a $27 \%$ (4-15 cases) rate of complete healing for non-recurrent fistula and reporting one case of anal abscess as a procedural complication. ${ }^{4}$ In reply to these findings, Attaallah et al. published their longterm results based on the analysis of the data obtained from a final cohort of 186 patients with a complete healing rate of $62 \%$ (95\% CI 58\%-64\%), with a median follow up period of 16 months (6-34 months). ${ }^{5}$

Tomasello et al. have published 3 clinical cases treated with Argentum-quarz solution describing complete healing in 2 of these, even though the follow up period was only of 4 months. ${ }^{6}$ In the same line, Utsunomiya et al. have reported a cohort of 113 infants diagnosed of perineal fistula treated with SN $30 \%$ solution, with an impressive complete healing rate of $73 \%$ without major complications. ${ }^{?}$

To conclude, we provide additional evidence for the use of SN $1 \%$ solution irrigation in recurrent o persistent anal fistula. We report a complete healing rate of $44.4 \%$ performing a non-invasive procedure, with a favourable safety profile, and feasible to perform in outpatient clinic. In our opinion, SN 1\% solution should be considered in patients with recurrent or persistent anal fistula after surgery, in absence of intermediate abscess and/or cavity; and risk of faecal incontinence or in those declining surgical treatment.

\section{Conflicts of interest}

The authors declare no conflicts of interest.

\section{REFERENCES}

1. Göttgens K, Smeets R, Stassen L, Beets G, Breukink S. Systematic review and meta-analysys of surgical intervencions for high cryptoglandular perianal fistula. Int J Colorectal Dis. 2015;30:583-93.

2. Attaallah W, Tuney D, Gulluoglu B, Ugurlu M, Guna O, Yegen C. Should we consider topical silver nitrate irrigation as a definitive nonsurgical treatment for perianal fistula? Di Colon Rectum. 2014;57:882-7.

3. Tomasello G, Bellavia M, Daminai F, Damiano G, Palumbo V, Fiorentini $\mathrm{T}$, et al. Argentum-quarz solution in the treatment of anorectal fistulas: is it possible a conservative approach? Med Hypoth. 2012;79:542-3.

4. Doll D, Vassiliu P. Silver nitrate for anal fistulas: a word of caution. Dis Colon Rectum. 2015;58:12.

5. Attaallah W, Gulluoglu B. The authors reply. Dis Colon Rectum. 2015;58:e460.

6. Tomasello G, Tralongo P, Di Trapani B, Carini F, Sinagra E, Oueudat D, et al. Efficacy of Argentum-Quartz solution in the treatment of perineal fistulas: a preliminary study. J Int Transl Med. 2015;3:167-71.

7. Utsunomiya T, Kikuta S, Shibate O, Yamabe M. Evaluation of the corrosive therapy of injection of silver nitrate solution into perianal fistulas in infants. Nipon Daicho Komonbyo Gakkai Zasshi. 2014;47:151-6. 